NBER WORKING PAPER SERIES

\title{
TRADE UNIONS AND THE DISPERSION \\ OF EARNINGS IN BRITISH \\ ESTABLISHMENTS, $1980-90$
}

Amanda Gosling

Stephen Machin

Working Paper No. 4732

\author{
NATIONAL BUREAU OF ECONOMIC RESEARCH \\ 1050 Massachusetts Avenue \\ Cambridge, MA 02138 \\ May 1994
}

The authors would like to thank the Economic and Social Research Council for financial support and Danny Blanchflower, Lorraine Dearden, Richard Freeman, Francis Green, Peter Ingram, Neil Millward, Andrew Oswald, John Schmitt, Mark Stewart, participants in the CEP WIRS3 Conference at LSE, the Fall 1993 Labor Studies meeting at NBER and in seminars at University College Dublin, LSE and the University of East Anglia for useful comments and suggestions. This paper is part of NBER's research program in Labor Studies. Any opinions expressed are those of the authors and not those of the National Bureau of Economic Research. 
NBER Working Paper \#4732

May 1994

\title{
TRADE UNIONS AND THE DISPERSION \\ OF EARNINGS IN BRITISH \\ ESTABLISHMENTS, $1980-90$
}

\begin{abstract}
The relationship between unions and earnings dispersion is examined using establishmentlevel data from the 1980, 1984 and 1990 Workplace Industrial Relations Surveys. Initially the cross-sectional relationship is examined using the 1990 data. The earnings dispersion of skilled and semi-skilled workers is seen to be lower across unionised establishments than across nonunion establishments; secondly, within-establishment eamings dispersion is lower in plants which recognise trade unions for collective bargaining purposes than in those that do not. All three surveys are then utilised to ascertain to what extent the decline in unionization in Britain has contributed to the rise in eamings inequality of semi-skilled workers. There was a sizable and important widening of the gap in the dispersion of eamings across union and non-union plants between 1980 and 1990. For semi-skilled earnings, the decline in the share of plants with recognised unions can account for 11-17\% of the rise in eamings inequality over this time period. The importance of falling union activity (as measured by union recognition) seemed to accelerate through the 1980s. Between 1980 and 1984 the relatively small falls in aggregate recognition explain less than 10\% of the inequality increase, whereas between 1984 and 1990 about onequarter of the increase can be accounted for by the fall in unionisation. The majority of the rise in earnings inequality is, however, due to a large increase in eamings dispersion across non-union establishments.
\end{abstract}

Amanda Gosling Institute for Fiscal Studies

7 Ridgmount Street London WC1E 7AE ENGLAND
Stephen Machin

Center for Economic Performance

London School of Economics

London WC2A 2AE

ENGLAND

and Harvard University and NBER 


\section{Introduction}

One of the most striking features of the UK labour market during the 1980s was a considerable rise in the inequality of eamings. In the 1980 distribution of male woekly earnings, the ratio of the 90th percentile of the distribution to the 10th percentile was 2.452; by 1990 this had dramatically risen to $3.106 .{ }^{1}$ For women there was also a large rise, albeit by slightly less in absolute magnitude (from 2.358 to 2.856 ).

The 1980 s also saw a marked decline in union presence. According to the three Workplace Industrial Relations Surveys that were conducted between 1980 and 1990, the percentage of private sector plants with recognised trade unions was $54 \%$ in $1980,50 \%$ in 1984 and $40 \%$ in 1990 (Millward et al., 1992). Other indicators of union presence suggest a similarly sharp fall: for instance, aggregate union membership fell from 13.2 million employees in 1980 to 9.9 million in 1990; the number of trade unions fell from 453 to 287 ; the corresponding fall in aggregate union density was from $54 \%$ to $38 \% .^{2}$

The aim of this paper is twofold. First, we use data from the recently available 1990 Workplace Industrial Relations Survey to establish the impact of unions on the distribution of earnings. Second, we document changes in this relationship between 1980 and 1990 by using data from the 1980, 1984 and 1990 Surveys, and thereby attempt to gauge the extent

'These figures are from the New Earnings Survey which also shows a dramatic rise for hourly earnings. The increases are driven by changes at both the top and the bottom of the distribution: for males (females) the ratio of the 90th percentile to the median hourly eamings rose from $1.616(1.613)$ to 1.811 (1.786) between 1980 and 1990; the male (female) decrease in the ratio of the 10 th percentile to the median was from $0.659(0.684)$ to 0.583 (0.625).

${ }^{2}$ See Bird et al. (1992), Waddington (1992) and Disney, Gosling and Machin (1994) for more details on trends in union activity over the 1980 s. 
to which the fall in unionisation through the 1980s can account for the coincident rise in earnings inequality.

The structure of the paper is as follows. Section II presents a brief survey of existing - mainly US - evidence on unions and earnings dispersion and on various explanations of the rise in earnings inequality (again mainly based on US work). Section III uses the 1990 Workplace Industrial Relations Survey to provide cross-sectional evidence on the impact of British unions on manual eamings dispersion. Section IV uses the 1980, 1984 and 1990 surveys to evaluate the contribution of falling union presence to the rise in eamings inequality for one particular group of workers (semi-skilled manuals) on which there exist comparable data in all three years. Finally, Section V offers some concluding remarks.

\section{Unions and Earnings Dispersion: Existing Work}

\section{Unions and the Dispersion of Earnings}

Theoretically, unions can influence the distribution of earnings in either a positive or a negative direction. If, as right-wing economists argue (notably Hayek, 1980 and Minford, 1983), the pay-raising (or monopoly) aspect of unionism is dominant, then unions, by pushing up the earnings of certain select groups in the economy, will increase inequality and dislodge lower-paid workers from employment. For instance, Hayek states "unions have become the biggest obstacle to raising the living standards of the working class as a whole. They are the chief cause of the unnecessarily big differences between the best and the worst paid workers" [Hayek, 1980, page 52]. On the other hand, others (e.g. Freeman and Medoff, 1984; Lewis, 1986) argue that unions have traditionally organised low-paid workers and have thus squeezed the distribution of earnings both within and across firms, occupations and 
industries.

The large body of US empirical evidence points to the dominance of the latter, indicating that unions are associated with reduced eamings dispersion (Freeman, 1980; Freeman, 1982; Hirsch, 1982). The finding is usually explained as compression resulting from union pay policies since unions typically organise lower-paid workers and attempt to standardise pay for given job definitions (Reynolds and Taft, 1956; Slichter, Healy and Livernash, 1960). Many have argued that unions act as a redistributive force and, in this respect, that unions can have a desirable influence on economic outcomes (see Freeman and Medoff, 1984, chapter 5). This is the mechanism behind what Flanders (1970) terms the 'sword of justice' effect of trade unions.

For the UK the evidence is more limited but, in accord with the US work, Metcalf (1982) uses data from the New Earnings Survey to show that unions reduce the inter-industry earnings distribution. Similarly, whilst it is not the main focus of his work, Stewart (1983a, 1987, 1991) reports standard deviations of in(eamings) that are lower for union than non-union establishments, based on National Training Survey data from 1975 and on data from the Workplace Industrial Relations Surveys of 1980 and $1984 .{ }^{3}$ Ingram (1991) reports a higher coefficient of variation amongst non-bargained pay settlements, using data from the CBI pay databank. Blanchflower and Freeman (1992) also find coefficients of variation to be lower for union workers in the UK, using data from the International Social Survey Programme. Finally, Millward et al. (1992) examine the proportion of establishments in the

3 Stewart's (1987, 1991) work also reports that the union/non-union earnings differential is lower for (higher paid) skilled workers than for semi-skilled workers (see, for example, Table 3 of Stewart, 1991) which also tends to compress the union sector distribution. 
1990 Workplace Industrial Relations Survey which employ low-paid workers. They report that $27 \%$ of private sector establishments have at least some workers with pay below the 10th percentile of the 1990 New Earnings Survey earnings distribution, but that the percentage is $19 \%$ in plants with recognised unions as compared to $32 \%$ in non-union plants. All these studies point to UK trade unions having an important equalising effect on earnings.

\section{Unions and Changes in Earnings Dispersion}

The 1980s saw a considerable rise in earnings dispersion in the UK, the US and in some other developed countries. The start of the US rise can be traced back to the late 1960s, whereas it appears that earnings inequality began to rise in the UK from about 1977 or 1978 onwards. Figure I plots the gap between the 90 th percentile and the 10th percentile of the male and female distributions of $\log$ (hourly earnings) between 1972 and 1990 to illustrate this trend increase through the $1980 \mathrm{~s}^{5}$ A voluminous literature which attempts to explain the US rise has emerged in recent years, though to date there is less UK research on the issue. 6

The US work provides at least three principal explanations for the rise in eamings

4 See, for example, Davis (1992) who provides a comprehensive description of trends in earnings inequality among 13 countries, or the description of changing wage structures in the UK, US, France and Japan by Katz, Loveman and Blanchflower (1993)

S Analogous plots illustrating the US experience can be found in Murphy and Welch (1992) or Juhn, Murphy and Pierce (1993) and in many other papers.

6 On the US rise in wage inequality see the February 1992 issue of the Quarterly Journal of Economics and the survey of Levy and Murnane (1992). Research in the UK is limited to a small number of pieces: see Atkinson (1993), Jenkins (1991) and Johnson and Webb on income inequality and Gregg and Machin (1993), Katz, Loveman and Blanchflower (1993) and Schmitt (1992) on the increase in the inequality of eamings. 
inequality. The first is that there has been an increase in the return to education so that the eamings gap between highly educated workers and those with few or no qualifications has widened. The second is that there has been an increase in the demand for skilled workers for whom employers are prepared to pay higher eamings, either as a result of skill-biased technical change (Krueger, 1993; Bound and Johnson, 1992) or increased import competition (Murphy and Welch, 1992). A third explanation is that the declining role of labour market institutions like unions and minimum wages, which have traditionally protected the wages of workers at the bottom of the pay distribution, has contributed to rising earnings inequality (Freeman, 1992). ${ }^{7}$

Whilst there is probably some merit in each of these explanations, we are interested here in the role of falling union activity in explaining the rise in eamings inequality. Recent US studies of this question have come to very similar conclusions despite using very different methodologies. Freeman (1992) uses simple variance decompositions to show that the fall in US union density between 1978 and 1988 can account for about $21 \%$ of the coincident rise in eamings inequality. Card (1991) uses a more sophisticated approach, based on quintile regressions, to reach much the same conclusion, namely that over the period $1973-87,21 \%$ of the increase in the variance of earnings can be accounted for by changes in the level and distribution of unionisation. A third study of interest is Freeman and Needels' (1993) comparison of changes in labour market inequality in the US and Canada. They find that declining unionisation has played an important role in the rise in inequality in the US, whilst

7 In the US in the 1980 s those at the lower end of the distribution actually became worse off in absolute terms, facing real pay decreases; in the UK, despite the considerable changes in the structure of wages, the bottom decile still achieved positive real pay changes. 
in Canada union presence has not fallen and inequality has also remained relatively unchanged. Finally, Lemieux (1993) and DiNardo and Lemieux (1993) use microdata sources to compare the impact of unions in Canada and the US. Lemieux (1993) concludes that approximately $40 \%$ of the Canada-US difference in male eamings inequality can be attributed to differences in union activity, whilst DiNardo and Lemieux (1993) present estimates indicating that the relative decline of unions, together with the eroded relative value of the US minimum wage, can account for the majority of the Canada-US differences in the evolution of wage inequality.

\section{Estimates of the Union Effect on Earmings Dispersion. 1990}

The Workplace Industrial Relations Survey of 1990

The 1990 Workplace Industrial Relations Survey is a nationally representative survey of 2061 establishments in Britain that employ 25 or more employees." In many respects it is very similar to the two earlier (1980 and 1984) surveys that are described in some detail in Daniel and Millward (1983) and Millward and Stevens (1986). Like the two preceding surveys, its main strength is on industrial relations issues though there is a little more economic information contained in the 1990 survey (for example, in a subset of establishments financial managers were asked to report information on profitability, costs, market structure etc.).

In this section we investigate the relationship between unions and the dispersion of

- More details are given in Millward et al. (1992). 
earnings using data from the 1990 Workplace Industrial Relations Survey. We approach this issue in two ways. The first is to consider the relationship between union status and the within-skill, across-establishment dispersion of the eamings of skilled and semi-skilled manual workers.' The second is to analyse across skill, within-establishment inequality by looking at a question asked only in the 1990 survey, which allows us to measure the upper and lower tails of the pay distribution of all full-time workers employed in the establishment.

\section{Across-Establishment Manual Earnings Inequality}

Managers were asked to report median weekly eamings of the typical majority sex worker in the relevant skill group and, as in both previous surveys, the data are banded into eleven categories, with the bottom and top pay bands being open-ended. To compute unconditional means and standard deviations we simply allocate midpoints to each of the closed bands and utilise Stewart's (1983b) Maximum Likelihood estimator (described below) to estimate the bottom and top pay levels. We also use this estimator to compute conditional standard deviations from the various eamings regressions reported on below. ${ }^{10}$

9 The reason for focusing on these groups of workers is that WIRS is not good on reporting non-manual pay data, having no data on managers and information only on a very heterogeneous classification (clerical workers). There are data on unskilled manual pay but we were unsure of its suitability for analysing dispersion since the same band intervals for the grouped pay data are specified for skilled, semi-skilled and unskilled workers: while the earnings distributions are reasonably good approximations to the log-normal for the (higher paid) skilled and semi-skilled, there is a large concentration of unskilled pay leveis in the bottom interval, rendering log-normality invalid. However, similar results did emerge if we used the unskilled and clerical pay data to draw union/non-union comparisons (see footnote 11).

10 The qualitative nature of the results is not sensitive to the choice of top and bottom band pay levels or to cruder grouping of the bands (we thank Francis Green and Mark Stewart for suggesting that we do this). For example, amalgamating the bottom two and the 
The upper panel of Table I reports the raw standard deviation of $\ln$ (earnings) for skilled and semi-skilled manual workers in the union and non-union segments of the private sector in 1990 . Union status is defined as the recognition of manual trade unions for collective bargaining purposes. In both cases the standard deviation is lower in the union sector: 13\% (skilled) and 19\% (semi-skilled) lower than the non-union standard deviation. The gap is significant at the $5 \%$ level of significance in both cases. ${ }^{11}$

There are a number of other possible reasons, beyond union status, why earnings dispersion may be lower in the union sector. Establishment-level characteristics such as size, ownership status and workforce composition are clearly important determinants of eamings and their variability. We can standardise for these establishment characteristics by computing regression-corrected Maximum Likelihood estimates of the standard deviation of In(earnings). As the eamings data are grouped, simple least-squares estimation procedures are inconsistent, so we use Stewart's (1983b) Maximum Likelihood estimator for grouped dependent variable models. This is a limited dependent variable procedure which estimates the overall and unobserved distribution as well as the conditional expectations. This estimator is based on using the available information on establishment characteristics to form the conditional expectation of earnings for each observation in the sample. One can then compute estimated standard deviations in the usual manner (more details are given in Stewart, 1983b).

top two bands to give nine bands produced a very similar pattern (i.e. skilled and semiskilled union/non-union differences were extremely similar).

11 Despite the qualifications noted in footnote 9 above, we also computed unconditional standard deviations for unskilled and clerical workers as: 0.341 in the union sector and 0.408 in the non-union sector for the unskilled, generating a gap and associated standard error of $-0.068(0.024)$; for clericals 0.231 (union), 0.261 (non-union), and a gap of $-0.030(0.012)$. 
We estimated separate union and non-union semi-logarithmic earnings equations controlling for plant size, various workforce plant and union characteristics (precise details on the controls are given in the notes to Table I). After including this (very stringent) set of controls, the estimated conditional standard deviation of ln(eamings) is higher in the non-union sector, though only by a little and not significantly so for skilled workers. For semi-skilled workers, however, the gap is large and statistically significant, providing strong evidence for the 'sword of justice' role of trade unions.

\section{Within-Establishment Earnings Inequality}

Unlike the two previous surveys the 1990 survey contained a question on within-establishment dispersion. The precise question had two parts - for the lower and upper ends of the earnings distribution - and is reproduced here:

-Please consider the average gross earnings of all full-time employees (including managers) at this establishment. Approximately what proportion of full-time employees earn half that amount or less? Approximately what proportion of full-time employees earn twice that amount or more?"

The nature of the question makes it evident that, in some plants with highly compressed earnings structures (with no very low-paid or high-paid employees), the proportion eaming twice or more / half or less than average will be zero. The data are thus censored at zero and we need to take account of this when we estimate regression models. We do so by using a Tobit estimator.

The raw data are described in Table II. Owing to their censored nature we provide two pieces of information: the proportion of plants with any workers paid $50 \%$ or less / 
$200 \%$ or more of average eamings, and the average proportion of workers in each of these categories (the average includes the zeros). Plants with recognised unions have lower within-plant eamings inequality (see also the description of the raw data in Millward et al., 1992, Table 7.15, pp.248-9). Unionised plants are less likely to have workers paid $50 \%$ or less and $200 \%$ or more than the average. Further, the proportion of workers that receive such low or high eamings (relative to the average) is higher in the non-union sector.

As in the case of across-establishment dispersion, this pattem may be shaped by various establishment-specific factors. In Table III we thus report Tobit estimates of the relation between within-establishment eamings dispersion and trade union recognition. Columns (1)-(3) consider the bottom end of the distribution (the $550 \%$ question) and columns (4)-(6) consider the top end ( $\geq 200 \%)$. In each case, the first column is a simple regression on a recognition dummy, the second includes plant and worker characteristics and the third additionally includes eight one-digit industry dummies.

For both questions, the estimated coefficient on the recognition dummy is negative and statistically significant (though only at the $10 \%$ level in column (1)). The effect at the top of the distribution is extremely precisely determined across all three specifications. Other noteworthy results include the significant impact of local labour market unemployment at the bottom end of the distribution and the important workforce composition and plant size effects.

It appears therefore that within-establishment eamings dispersion is also lower in the presence of unions. Trade unions have an equalising impact at both ends of the within-establishment distribution of eamings. The 'sword of justice' effect appears to receive support from the relationship between unions and eamings dispersion, both in 
across-establishment and within-establishment comparisons.

\section{Changes in the Union-Earnings Dispersion Relationshlo, 1980-1990}

The previous section pointed to an important eamings-equalising effect of unions in 1990. However, there were considerable changes in eamings dispersion in the 1980s. In this section we therefore use the three Workplace Industrial Relations Surveys (of 1980, 1984 and 1990) to examine changes in the relationship between unions and across-establishment inequality between 1980 and 1990 . We focus on one group of workers for whom we have data in all three years, the semi-skilled, and report union/non-11;ion comparisons of dispersion over time. ${ }^{12}$

Panel 1 of Table IV reports unconditional standard deviations of In(earnings) for semi-skilled workers in union and non-union plants for the three available years. In 1980 the gap between union and non-union dispersion (in terms of unconditional standard deviations) was -0.028 ; in 1984 the gap widened to -0.063 and by 1990 it became -0.066 . All gaps are significantly different from zero, though only at the $10 \%$ level in 1980 . Whilst dispersion grew among both union and non-union plants, it appears that the non-union distribution opened up by more over the 1980 s.

12 Another possible approach would be to use the 1984-90 panel of just over 500 trading sector establishments. However, the sample size became very small after allowing for missing data and making samples consistent between the two years due to differences in responses to the earnings question (in 1990 responses were sought only if the establishment had at least five workers in the appropriate skill group). Examination of the characteristics of these plants led us to believe that, mainly because of this $5+$ requirement, they were unrepresentative of the overall population (e.g. they were larger and more unionised). We therefore remained reluctant to use the panel for modeling earnings (of course, this should not detract from the use of the panel to study other issues). 
In Panel 2 we report regression-corrected conditional standard deviations, together with union/non-union differences. The pattem is robust to the inclusion of controls: in all cases, union dispersion is lower than non-union dispersion (though only just in 1980 and it is not different from zero in terms of statistical significance). The gap widens through the 1980 s and the rise is strongly significant in conventional statistical terms: adopting a "differences-in-differences" approach shows a 1980 to 1990 change of -0.045 with an associated standard error of 0.021 . Furthermore, in the union sector the regression controls are able to explain the majority of the observed rise in dispersion that is depicted by the unconditional standard deviations in Panel 1. Finally, to put it another way, the importance of unionisation is clearly illustrated when one views that, in the union sector between 1980 and 1990 , the conditional standard deviation rises by 0.023 (or $12 \%$ of the 1980 standard deviation) as compared to a $0.069(34 \%)$ rise in the non-union sector.

There is, however, an important issue of comparability of the earnings data across years. First, the eamings question in 1980 was different from the question asked in the later years. Second, the question in 1990 (whilst having the same format as the 1984 question) was only asked for plants which had 5 or more of the skill group in question (here the semi-skilled). More specifically, the 1980 question asked managers to give the weekly earnings of the typical employee in the appropriate skill group. In 1984 and 1990 managers were first asked to state whether there were more men or women in a particular skill group (in 1990 only if there were 5 or more workers in the skill group) and then to report the typical pay of this majority sex worker.

We have done some further checks on this. Table IV also reports union/non-union earnings dispersion gaps when one restricts the 1980 and 1984 data to cover only workplaces 
with 5 or more semi-skilled employees. A similar pattern emerges, with the gap if anything becoming wider through the 1980 s. Based on consistent sample definitions, the union/non-union dispersion gap in the conditional standard deviation widens from -0.010 in 1980 to -0.058 in 1990 .

To analyse the importance of falling union activity through the 1980 s for the overall rise in inequality, note that the variance of $\ln (r e a l$ eamings), say $V(w)$, can be written as

$$
V(w)=U \cdot V\left(w^{\prime \prime}\right)+(1-U) \cdot V\left(w^{0}\right)+U \cdot(1-U) \cdot\left(w^{w}-w^{n}\right)^{2}
$$

where $\mathrm{U}$ is the proportion of unionised plants and $\mathrm{u}$ and $\mathrm{n}$ superscripts denote union and non-union status respectively. The variance of eamings can thus be decomposed into a weighted combination of the union and non-union sector variances plus an interaction term based on the union earnings gap. One can think of the first two terms as picking up withinsector changes in the structure of earnings, and the third term as capturing between-sector changes due to trade union related wage differences. Using this decomposition, it is possible to compute the predicted variation of in(eamings) in 1990 had the 1980 union structure prevailed and compare it to the actual 1990 variance. The gap between these two gives an indication to the importance of the decline in unionism for the rise in the inequality of earnings.

In the upper panel of Table V we report the 1980 and 1990 computations of $V(w)$, together with the simulated value in 1990 had the 1980 union structure prevailed. We report four experiments which differ in whether they utilise weighted or unweighted union proportions and on whether they use the full sample of establishments or restrict to those which have at least five semi-skilled workers. We use the conditional standard deviations from the regression models of semi-skilled eamings reported in Table IV, together with 
Stewart's (1991, 1992) estimates of the ceteris paribus semi-skilled union/non-union In(earnings) gap of 0.066 in 1980 and 0.062 in 1990.

For all four cases, the first two rows of the upper panel of Table $\mathrm{V}$ adequately illustrate the sharp rise in the variance of earnings between 1980 and 1990 . In the third row we report the value of $\mathrm{V}(w)$ that our models predict would have been present in 1990 had the union structure of 1980 still been in place (i.e. using the 1980 value of U). As one would expect, this is lower in all cases. Finally, the fourth row of Table V computes the percentage contribution of the 1980 to 1990 fall in unionisation. Depending on the experiment considered, this ranges between 11 and $17 \%$.

The lower two panels of the Table perform the same analysis for the two sub-periods 1980-84 and 1984-90. The latter period is where the majority of the $1980-90$ decline in unionisation occurred. Not surprisingly, then, the impact of falling unionisation is more marked in the second sub-period. Effects are small, and can explain less than $10 \%$ of the inequality rise, between 1980 and 1984; on the other hand, between 1984 and 1990 the observed decline in union activity is an important contributor to the rise in the inequality of the earnings of semi-skilled manual workers and can account for between one-fifth and onequarter of the observed increase.

Hence, on average, the decline in unionisation accounts for somewhere around $15 \%$ of the rise in the variance of semi-skilled earnings between 1980 and 1990 . This is similar to the US findings of Card (1991) and Freeman (1993), who report that the US decline accounts for about $20 \%$ of the US rise in the variance of male earnings between the 1970 s and 1980s. Given the very large changes in the UK wage structure that occurred during the eighties, the decline in union activity thus appears to be an important factor. Nevertheless, 
the majority of the rise in across-establishment semi-skilled earnings dispersion between 1980 and 1990 is due to increased inequality in the non-union sector. ${ }^{13}$

\section{v. Concluding Remarks}

In this paper we have examined two related issues. The first concerns the relationship between union presence and earnings dispersion. In empirical work based on the 1990 Workplace Industrial Relations Survey we find that the distribution of earnings is more compressed in plants with recognised trade unions. This is the case for across-establishment comparisons of the distribution of skilled and semi-skilled manual earnings and for comparisons of within-establishment earnings distributions. Unfortunately the nature of the data precludes us from analysing whether across- or within-plant pay compression is the more important and from satisfactorily analysing the relation between unions and the dispersion of non-manual pay.

The second part of the paper considers changes in the relationship between unions and eamings dispersion using all three Workplace Industrial Relations Surveys. For the semi-skilled, pay dispersion rose in both union and non-union sectors during the 1980 s, but by much more in the non-union sector. The decline in unionisation appears to account for around $15 \%$ of the increase in the across-establishment dispersion of semi-skilled eamings

\footnotetext{
${ }^{13}$ One aspect of the larger increase in the non-union sector may be the weakening of minimum wage protection for low paid non-union workers via the reduced importance of the Wages Councils which culminated in their abolition in August 1993. Machin and Manning (1994) and Dickens et al. (1993) provide evidence that the failure to upgrade Wages Council minima was in fact associated with rising pay dispersion within Wages Council sectors. More generally, rises in the rate of return to education (Schmitt, 1992), the observed increase in the relative demand for skilled workers (Machin, 1994) and perhaps the increase in unemployment are likely to be important correlates of the overall rise in inequality.
} 
between 1980 and 1990 . The majority of the aggregate fall in union activity (based on union recognition) took place in the second half of the decade and the importance of declining unionism is more marked in the 1984-1990 time period where it can account for up to onequarter of the rise in inequality. The remainder appears to be largely attributable to a big rise in earnings inequality in the non-union sector.

Comparison with other work on this subject suggests an interesting cross-country pattern (see Davis, 1992, for a discussion of international trends in the structure of wages). It appears that countries with declining union activity have experienced coincident rises in earnings inequality - the US since the late sixties, the UK through the eighties. On the other hand, earnings inequality has stayed relatively constant in other countries (e.g. France or Canada) where the degree of unionisation has also remained constant or risen (see Katz et a1., 1993, on France and Lemieux, 1993, DiNardo and Lemieux, 1993, and Freeman and Needels, 1993, on Canada). Caution should be exercised in drawing strong conclusions from this since the economic experiences of these countries have been very diverse and the role played by trade unions in different countries has been quite varied. Nevertheless, the results suggest that the decline in unionisation is an important feature of recent changes in earnings inequality in industrialised countries. 


\section{Eigure I:}

Male and Female Hourly Eamines Inequality in the UK, 1972-90
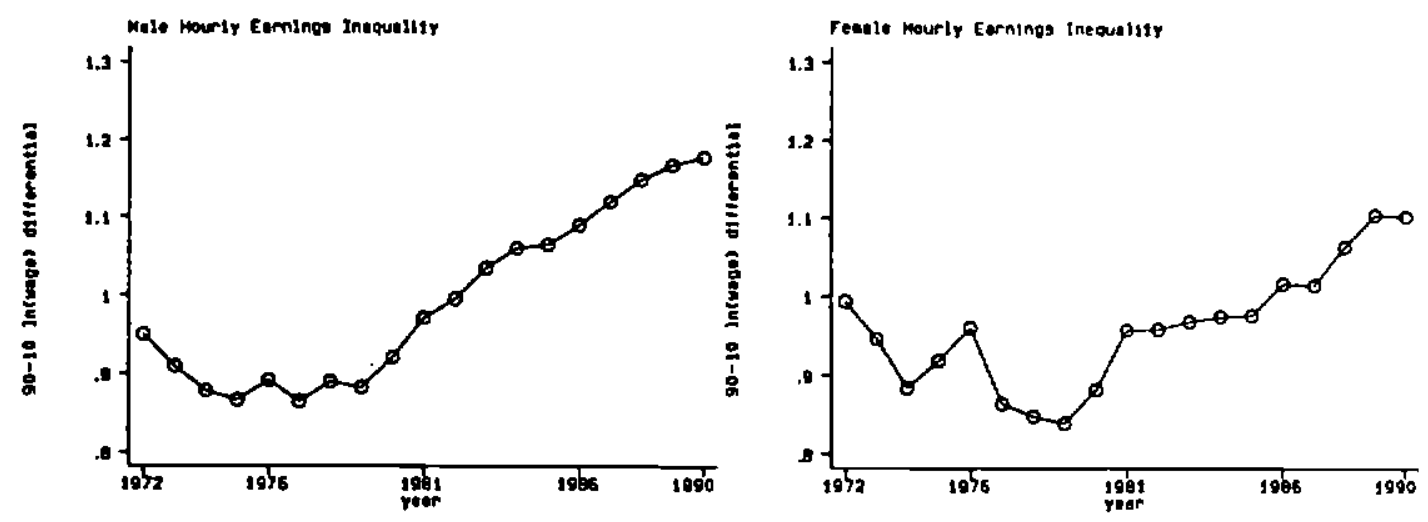

These are the difference between the $\log$ of the $90 \mathrm{th}$ and 10th percentiles of the male and female hourly earnings distribution (Source: New Eamings Survey). 
Table I: Unions and Eamings Dispersion. 1990 WIRS

\begin{tabular}{|c|c|c|c|}
\hline \multicolumn{4}{|c|}{$\begin{array}{l}\text { 1. Moximum Likelihood estimates of unconditional standard deviation of } \\
\text { In(earnings) }\end{array}$} \\
\hline & Union & Non-union & $\begin{array}{l}\text { Difference } \\
\text { (Standard Error) }\end{array}$ \\
\hline Skilled & 0.278 & 0.320 & $-0.042(0.019)$ \\
\hline Semi-skilled & 0.290 & 0.356 & $-0.066(0.021)$ \\
\hline \multicolumn{4}{|c|}{$\begin{array}{l}\text { 2. Maximum Likelihood estimates of conditional standard deviation from } \\
\text { In(earnings) regression }\end{array}$} \\
\hline & Union & Non-union & $\begin{array}{l}\text { Difference } \\
\text { (Standard Error) }\end{array}$ \\
\hline Skilled & 0.224 & 0.237 & $-0.013(0.015)$ \\
\hline Semi-skilled & 0.211 & 0.270 & $-0.058(0.021)$ \\
\hline \multicolumn{4}{|c|}{ 3. Number of establishments (unweighted / weighted) } \\
\hline & Union & Non-union & $\begin{array}{l}\text { Percentage } \\
\text { Union }\end{array}$ \\
\hline Skilled & $473 / 257$ & $216 / 306$ & $68.7 / 45.7$ \\
\hline Semi-skilled & $395 / 201$ & $219 / 286$ & $64.3 / 41.3$ \\
\hline
\end{tabular}

Notes

1. Union status is defined as any union recognised for collective bargaining purposes for manual workers.

2. The regressions are Maximum Likelihood estimates for union and non-union sectors. We are grateful to Mark Stewart for letting us use his Maximum Likelihood estimation procedure. Controls included are: 5 plant size dummies, manual, part-time, skilled, semi-skilled and female proportions, dummy variables for majority sex male, manufacturing, single site, shift work, payment-by-results, UK owned, employer's association and (in the union sector) existence of pre- or post-entry closed shop arrangements. 
Table II: Descriptive Information on Within-Establishment Earmings Dispersion

\begin{tabular}{|c|c|c|c|}
\hline \multicolumn{4}{|c|}{ 1. Average Earnings of $50 \%$ or less than average } \\
\hline & $\begin{array}{l}\text { Proportion of } \\
\text { establishments with } \\
\text { some workers paid } \\
50 \% \text { or less }\end{array}$ & $\begin{array}{l}\text { Proportion of } \\
\text { workers who are } \\
\text { paid } 50 \% \text { or less }\end{array}$ & $\begin{array}{l}\text { Number of } \\
\text { establishments with } \\
\text { usable responses } \\
\text { (unweighted / } \\
\text { weighted) }\end{array}$ \\
\hline All establishments & 0.464 & 0.113 & $1165 / 1185$ \\
\hline $\begin{array}{l}\text { Establishments } \\
\text { with recognised } \\
\text { union(s) }\end{array}$ & 0.415 & 0.095 & $643 / 465$ \\
\hline $\begin{array}{l}\text { Establishments } \\
\text { with no recognised } \\
\text { union }\end{array}$ & 0.495 & 0.126 & $522 / 720$ \\
\hline \multicolumn{4}{|c|}{ 2. Average Earnings of $200 \%$ or more than average } \\
\hline & $\begin{array}{l}\text { Proportion of } \\
\text { establishments with } \\
\text { some workers paid } \\
200 \% \text { or more }\end{array}$ & $\begin{array}{l}\text { Proportion of } \\
\text { workers who are } \\
\text { paid } 200 \% \text { or more }\end{array}$ & $\begin{array}{l}\text { Number of } \\
\text { establishments with } \\
\text { usable responses } \\
\text { (unweighted / } \\
\text { weighted) }\end{array}$ \\
\hline All establishments & 0.724 & 0.056 & $1176 / 1203$ \\
\hline $\begin{array}{l}\text { Establishments } \\
\text { with recognised } \\
\text { union(s) }\end{array}$ & 0.680 & 0.042 & $652 / 474$ \\
\hline $\begin{array}{l}\text { Establishments } \\
\text { with no recognised } \\
\text { union }\end{array}$ & 0.752 & 0.066 & $524 / 729$ \\
\hline
\end{tabular}

\section{Notes}

1. Weighted proportions, weights being WIRS weights.

2. The proportion of workers paid $50 \%$ or below $/ 200 \%$ or above average are calculated for all establishments (i.e. including the 0 's). 
Table II: Determinants of Within-Establinhmem Perninge Dimpersion in 1990

\begin{tabular}{|c|c|c|c|c|c|c|}
\hline & \multicolumn{3}{|c|}{$\begin{array}{l}\text { Proportion with earnings of } 50 \% \text { or leas then } \\
\text { overngo }\end{array}$} & \multicolumn{3}{|c|}{$\begin{array}{l}\text { Proportion with earnings of } 200 \% \text { or more } \\
\text { then averege }\end{array}$} \\
\hline & (l) & (2) & (3) & (4) & (5) & (6) \\
\hline Constad & $\begin{array}{l}0.008 \\
(0.017)\end{array}$ & $\begin{array}{l}0.030 \\
0.060\end{array}$ & $\begin{array}{l}-0.052 \\
(0.086)\end{array}$ & $\begin{array}{l}0.060 \\
(0.004)\end{array}$ & $\begin{array}{l}0.075 \\
0.015)\end{array}$ & $\begin{array}{l}0.076 \\
(0.021)\end{array}$ \\
\hline Union rocognined & $\begin{array}{l}-0.038 \\
(0.021)\end{array}$ & $\begin{array}{l}-0.076 \\
0.025)\end{array}$ & $\begin{array}{l}-0.065 \\
(0.024)\end{array}$ & $\begin{array}{l}-0.029 \\
(0.006)\end{array}$ & $\begin{array}{l}-0.031 \\
(0.006)\end{array}$ & $\begin{array}{l}-0.030 \\
(0.006)\end{array}$ \\
\hline sa-99 enployees & & $\begin{array}{l}0.015 \\
(0.036) \\
\end{array}$ & $\begin{array}{r}0.019 \\
(0.036)\end{array}$ & & $\begin{array}{r}0.014 \\
(0.009) \\
\end{array}$ & $\begin{array}{l}0.016 \\
(0.008)\end{array}$ \\
\hline 100-199 exployen & & $\begin{array}{l}0.012 \\
(0.037)\end{array}$ & $\begin{array}{l}0.021 \\
0.006\end{array}$ & & $\begin{array}{l}0.034 \\
(0.009)\end{array}$ & $\begin{array}{l}0.034 \\
(0.009)\end{array}$ \\
\hline $200-499$ exployeed & & $\begin{array}{l}0.065 \\
(0.035)\end{array}$ & $\begin{array}{l}0.074 \\
(0.035)\end{array}$ & & $\begin{array}{l}0.030 \\
(0.009)\end{array}$ & $\begin{array}{c}0.031 \\
(0.009)\end{array}$ \\
\hline 500-999 employees & & $\begin{array}{l}0.043 \\
(0.043)\end{array}$ & $\begin{array}{l}0.059 \\
(0.044)\end{array}$ & & $\begin{array}{l}0.030 \\
(0.010)\end{array}$ & $\begin{array}{l}0.033 \\
(0.010)\end{array}$ \\
\hline $1000+$ employes & . & $\begin{array}{r}0.060 \\
(0.042) \\
\end{array}$ & $\begin{array}{r}0.071 \\
(0.047) \\
\end{array}$ & & $\begin{array}{l}0.060 \\
(0.010)\end{array}$ & $\begin{array}{c}0.042 \\
(0.010)\end{array}$ \\
\hline Pan-fimo proportion & & $\begin{array}{l}-0.249 \\
(0.050)\end{array}$ & $\begin{array}{l}-0.287 \\
(0.065)\end{array}$ & & $\begin{array}{l}-0.023 \\
(0.013)\end{array}$ & $\begin{array}{l}-0.021 \\
(0.014)\end{array}$ \\
\hline Female proportion & & $\begin{array}{l}0.119 \\
(0.059)\end{array}$ & $\begin{array}{l}0.103 \\
(0.063)\end{array}$ & & $\begin{array}{l}0.024 \\
(0.014)\end{array}$ & $\begin{array}{l}0.013 \\
(0.015)\end{array}$ \\
\hline Mnevel proportion & & $\begin{array}{l}-0.085 \\
(0.045) \\
\end{array}$ & $\begin{array}{l}-0.097 \\
0.047)\end{array}$ & & $\begin{array}{l}-0.063 \\
(0.011)\end{array}$ & $\begin{array}{l}-0.067 \\
(0.011)\end{array}$ \\
\hline No manent wortsen & & $\begin{array}{l}-0.080 \\
(0.043)\end{array}$ & $\begin{array}{l}-0.082 \\
(0.044)\end{array}$ & & $\begin{array}{l}0.013 \\
(0.010)\end{array}$ & $\begin{array}{l}0.007 \\
0.010)\end{array}$ \\
\hline Manofetenring & & $\begin{array}{l}-0.003 \\
(0.020)\end{array}$ & $\begin{array}{l}0.005 \\
(0.032)\end{array}$ & & $\begin{array}{l}-0.001 \\
(0.007)\end{array}$ & $\begin{array}{l}0.006 \\
(0.016)\end{array}$ \\
\hline UK-owned & & $\begin{array}{l}-0.033 \\
(0.043)\end{array}$ & $\begin{array}{l}-0.036 \\
(0.041)\end{array}$ & & $\begin{array}{l}-0.009 \\
(0.011)\end{array}$ & $\begin{array}{l}-0.009 \\
(0.011)\end{array}$ \\
\hline $\begin{array}{l}\text { Local labour merket } \\
\text { unemployment mle }\end{array}$ & & $\begin{array}{l}0.009 \\
(0.004)\end{array}$ & $\begin{array}{l}0.010 \\
(0.009)\end{array}$ & & $\begin{array}{l}0.0001 \\
(0.001)\end{array}$ & $\begin{array}{l}0.001 \\
(0.001)\end{array}$ \\
\hline Inctuatry dumunies & No & No & Yes & No & No & Yos \\
\hline Log-Likelihood & -3046.77 & .3023 .29 & -3016.70 & -3306.97 & .3257 .07 & -3230.93 \\
\hline Number of cacoblishments & 1076 & 1076 & 1076 & 1085 & 1085 & 1085 \\
\hline $\begin{array}{l}\text { Number of emubliahmonts } \\
\text { with proportion }=0\end{array}$ & 526 & 526 & 526 & 228 & 228 & 228 \\
\hline
\end{tabular}

Noles

1. Thew on Tobit eatimates; symptotic anodard erron in parentheses.

2. Other varinblea that were included but wero atways innignificant and were therefore omithed from the reported epecifications were: member of an employers' awociation; aingle sive; thilled and remi-abilled proportion; various non-linesrities in wortforce componition veriables. 
Table rV:

Chunres in the Union-Real Faminat Ditpervion Relationthio 1980-1990

\begin{tabular}{|c|c|c|c|c|c|c|}
\hline \multicolumn{7}{|c|}{ 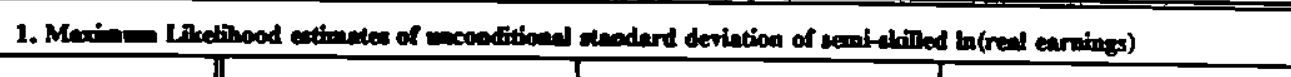 } \\
\hline & \multicolumn{2}{|c|}{1980} & \multicolumn{2}{|c|}{1984} & \multicolumn{2}{|c|}{1990} \\
\hline & Union & Non-union & Union & Non-union & Union & Non-union \\
\hline 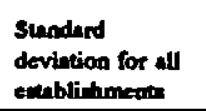 & 0.245 & 0.274 & 0.277 & 0.340 & 0.290 & 0.356 \\
\hline $\begin{array}{l}\text { Union/Noo- } \\
\text { union Difference } \\
\text { (Sundard Error) }\end{array}$ & \multicolumn{2}{|c|}{$\begin{array}{l}-0.028 \\
(0.016)\end{array}$} & \multicolumn{2}{|c|}{$\begin{array}{l}-0.063 \\
(0.018)\end{array}$} & \multicolumn{2}{|c|}{$\begin{array}{l}-0.066 \\
(0.021)\end{array}$} \\
\hline $\begin{array}{l}\text { Sundard } \\
\text { devietion: } \\
\text { entublichmens } \\
\text { with } S \text { of more } \\
\text { semi-abilled } \\
\text { worter }\end{array}$ & 0.243 & 0.274 & 0.266 & 0.321 & 0.290 & 0.356 \\
\hline $\begin{array}{l}\text { UnionNon- } \\
\text { union Difference } \\
\text { (Standard Error) }\end{array}$ & \multicolumn{2}{|c|}{$\begin{array}{l}-0.031 \\
(0.017)\end{array}$} & \multicolumn{2}{|c|}{$\begin{array}{l}-0.055 \\
(0.021)\end{array}$} & \multicolumn{2}{|c|}{$\begin{array}{l}-0.066 \\
(0.021)\end{array}$} \\
\hline \multicolumn{7}{|c|}{ 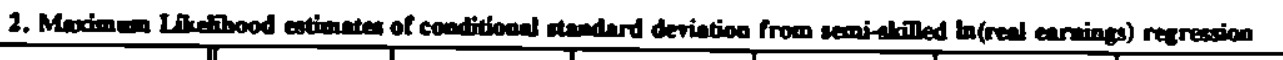 } \\
\hline $\begin{array}{l}\text { Sundard } \\
\text { devistion for all } \\
\text { extablishmenits }\end{array}$ & 0.188 & 0.201 & 0.206 & 0.241 & 0.211 & 0.270 \\
\hline $\begin{array}{l}\text { Union/Noos- } \\
\text { union Difierence } \\
\text { (Standerd Error) }\end{array}$ & \multicolumn{2}{|c|}{$\begin{array}{l}-0.013 \\
(0.012)\end{array}$} & \multicolumn{2}{|c|}{$\begin{array}{l}-0.035 \\
(0.018)\end{array}$} & \multicolumn{2}{|c|}{$\begin{array}{l}-0.058 \\
(0.021)\end{array}$} \\
\hline $\begin{array}{l}\text { Stendard } \\
\text { deviation: } \\
\text { exabliarhments } \\
\text { with S or more } \\
\text { cemi-atilled } \\
\text { worter }\end{array}$ & $0.185^{\circ}$ & 0.195 & 0.191 & 0.219 & 0.211 & 0.270 \\
\hline $\begin{array}{l}\text { Umion/Non- } \\
\text { Uxion Difference } \\
\text { (Sunderd Error) }\end{array}$ & \multicolumn{2}{|c|}{$\begin{array}{l}-0.010 \\
(0.012)\end{array}$} & \multicolumn{2}{|c|}{$\begin{array}{l}-0.028 \\
(0.015)\end{array}$} & \multicolumn{2}{|c|}{$\begin{array}{l}-0.058 \\
(0.021)\end{array}$} \\
\hline \multicolumn{7}{|c|}{ 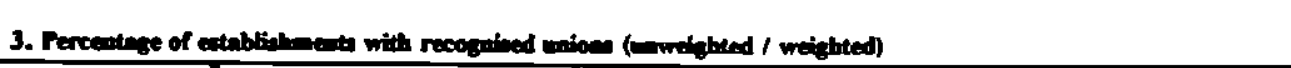 } \\
\hline $\begin{array}{l}\text { All } \\
\text { expublishmerts }\end{array}$ & \multicolumn{2}{|c|}{$74 / 51$} & \multicolumn{2}{|c|}{$69 / 50$} & \multicolumn{2}{|c|}{$64 / 41$} \\
\hline $\begin{array}{l}\text { Exenblishmeate } \\
\text { with } S \text { or more } \\
\text { wemi-alinled } \\
\text { wortere }\end{array}$ & \multicolumn{2}{|c|}{$75 / 51$} & \multicolumn{2}{|c|}{$74 / 54$} & \multicolumn{2}{|c|}{$64 / 41$} \\
\hline
\end{tabular}

Noles

1. A for Tablo 1 . 
Teble $\mathbf{V}_{\text {i }}$

The Efiect of the Dexlipe in Unionism on the Vorianse of Ln(Eamingo), 1980-90

\begin{tabular}{|c|c|c|c|c|}
\hline & $\begin{array}{l}\text { All anablichments: } \\
\text { unweighted U }\end{array}$ & $\begin{array}{l}\text { All extrablithmenes: } \\
\text { weighted U }\end{array}$ & $\begin{array}{l}\text { Enablishments with } \\
5 \text { or more ceml. } \\
\text { skilled workers: } \\
\text { unweighted U }\end{array}$ & $\begin{array}{l}\text { Eubblishments with S } \\
\text { or mone nemi-skilled } \\
\text { vorters: weighted U }\end{array}$ \\
\hline \multicolumn{5}{|c|}{ 1. $19 \% 0$ - 1990 Changer } \\
\hline$V(w)$ in 1980 & 0.0375 & 0.0389 & 0.0360 & 0.0372 \\
\hline$V(w)$ in 1990 & 0.0556 & 0.0622 & 0.0556 & 0.0622 \\
\hline $\begin{array}{l}V(w) \text { in } 1990 \\
\text { roplecing } 1990 \\
\text { velues of U with } \\
1980 \text { vahes }\end{array}$ & 0.0526 & 0.0593 & 0.0523 & 0.0594 \\
\hline $\begin{array}{l}\text { Percentugs } \\
\text { comribution of } \\
1980-90 \text { fill in } U \text { to } \\
1980-90 \text { ries in } V(w)\end{array}$ & 17 & 12 & 17 & 11 \\
\hline \multicolumn{5}{|l|}{ 2. 1990 - 1994 Chanes } \\
\hline$V(w)$ in 1980 & 0.0375 & 0.0389 & 0.0360 & 0.0372 \\
\hline$V(w)$ in 1984 & 0.0490 & 0.0520 & 0.0408 & 0.0435 \\
\hline $\begin{array}{l}V(\varpi) \text { in } 1984 \\
\text { replecing } 1984 \\
\text { vahues of } U \text { wilh } \\
1980 \text { valuo }\end{array}$ & 0.0479 & 0.0519 & 0.0407 & 0.0438 \\
\hline $\begin{array}{l}\text { Porcentegse } \\
\text { contribution of } \\
1980-84 \text { till in } U \text { to } \\
1980-84 \text { rive in } V(w)\end{array}$ & 8 & $\mathbf{1}$ & 2 & 0 \\
\hline \multicolumn{5}{|c|}{ 3. $19 \% 4$ - 1990 Changen } \\
\hline$V(w)$ in 1984 & 0.0488 & 0.0520 & 0.0408 & 0.0435 \\
\hline$V(w)$ in 1990 & 0.0556 & 0.0622 & 0.0556 & 0.0622 \\
\hline $\begin{array}{l}\mathrm{V}(w) \text { in } 1990 \\
\text { replecing } 1990 \\
\text { velues of } U \text { with } \\
1984 \text { value }\end{array}$ & 0.0541 & 0.0597 & 0.0526 & 0.0585 \\
\hline $\begin{array}{l}\text { Percentinge } \\
\text { contribution of } \\
194490 \text { fall in } U \text { to } \\
1944-90 \text { rise in } V(w)\end{array}$ & 22 & 25 & 20 & 20 \\
\hline
\end{tabular}

Notey

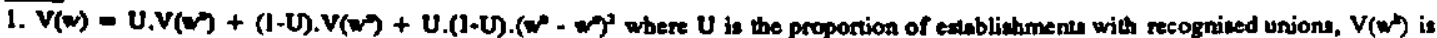

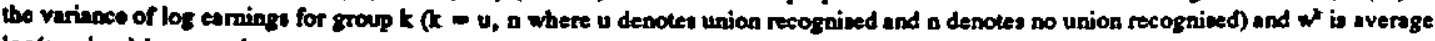
log(earniags) in group $\mathbf{k}$.

2. The vahue uned to compute $V(w)$ are tokes from panel 2 of Table IV, together with Stewart's (1991, 1992) ceteris poribus extimates of $w$ - of 0.066 in $1980,0.084$ in 1984 and 0.062 in 1990 . 


\section{References}

Atkinson, Anthony (1993) 'What is happening to the distribution of income in the UK', STICERD Discussion Paper No. 87.

Bird, Derek, Michael Kirosingh and Mark Stevens (1992) 'Membership of trade unions in 1990', Employment Gazette, 185-90.

Blanchflower, David and Richard Freeman (1992) 'Unionism in the United States and other advanced OECD countries', Industrial Relations, 31, 56-79.

Bound, John and George Johnson (1992) 'Changes in the structure of wages in the 1980s: An evaluation of alternative explanations', American Economic Review, 82, 371-92.

Card, David (1991) 'The effect of unions on the distribution of wages: Redistribution or relabelling?', Princeton University Industrial Relations Section Discussion Paper 287.

Daniel, William and Neil Millward (1983) Workplace Industrial Relations in Britain, London: Heinemann.

Davis, Steven (1992) 'Cross-country patterns of change in relative wages', NBER Macroeconomics Annual, 239-300.

Dickens, Richard, Stephen Machin and Alan Manning (1993) 'The employment effects of minimum wages: Theory and evidence from the UK', University College London Discussion Paper 93-13.

DiNardo, John and Thomas Lemieux (1993) 'Diverging wage inequality in the United States and Canada, 1981-88: Do unions explain the difference?', mimeo.

Disney, Richard, Amanda Gosling and Stephen Machin (1994) 'British unions in decline: An examination of the 1980s fall in trade union recognition', Institute for Fiscal Studies Discussion Paper 94/4.

Flanders, Allan (1970) Management and Unions: The Theory and Reform of Industrial Relations, London: Faber.

Freeman, Richard (1980) 'Unionism and the dispersion of wages', Industrial and Labor Relations Review, 34, 3-24.

Freeman, Richard (1982) 'Union wage practices and wage dispersion within establishments', Industrial and Labor Relations Review, 36, 3-21. 
Freeman, Richard (1993) 'How much has deunionization contributed to the rise in male camings inequality?', in Sheldon Danziger and Peter Gottschalk (eds.) Uneven Tides: Rising Inequality in America, New York: Russell Sage Foundation.

Freeman, Richard and James Medoff (1984) What Do Unions Do?, New York: Basic Books.

Freeman, Richard and Karen Needels (1993) 'Skill differentials in Canada in an era of rising wage inequality', in David Card and Richard Freeman (eds.) Small Differences that Matter: Labor Markets and Income Maintenance in Canada and the United States, Chicago: University of Chicago Press.

Gregg, Paul and Stephen Machin (1993) 'Is the UK rise in inequality different?', in R. Barrell (ed.) The UK Labour Market, Cambridge: Cambridge University Press.

Hayek, Friedrich (1980) 1980s Unemployment and the Unions, Institute for Economic Affairs Hobart Paper 87.

Hirsch, Barry (1982) The interindustry structure of unionism, earnings and eamings dispersion', Industrial and Labor Relations Review, 1, 36, 22-39.

Ingram, Peter (1991) 'Ten years of manufacturing wage settlements: 1979-89', Oxford Review of Economic Policy, 7, 93-106.

Jenkins, Stephen (1991) 'Accounting for inequality trends: decomposition analyses for the UK 1971-86', University College Swansea mimeo.

Johnson, Paul and Stephen Webb (1993) 'Explaining the growth in UK income inequality: 1979-88', Economic Joumal Conference Volume, 103, 429-35.

Juhn, Chinhui, Kevin Murphy and Brooks Pierce (1993) 'Wage inequality and the rise in returns to skill', Loumal of Political Economy, 101, 410-42.

Katz, Lawrence, Gary Loveman and David Blanchflower (1993) 'An intemational comparison of changes in the structure of wages: France, the United Kingdom and the United States', Centre for Economic Performance Discussion Paper No. 144.

Krueger, Alan (1993) 'How computers have changed the wage structure: evidence from microdata, 1984-89', Quarterly Journal of Economics, 93, 33-60.

Lemieux, Thomas (1993) 'Unions and wage inequality in Canada and the United States', in David Card and Richard Freeman (eds.) Small Differences that Matter: Labor Markets and Income Maintenance in Canada and the United States, Chicago: University of Chicago Press. 
Levy, Frank and Richard Murnane (1992) 'US eamings levels and eamings inequality: A review of recent trends and proposed explanations', Joumal of Economic Literature, $30,1333-81$.

Lewis, H. Gregg (1986) Union Relative Wage Effects: A Survey, Chicago University Press.

Machin, Stephen (1994) 'Changes in the relative demand for skills in the UK labour market', forthcoming in Alison Booth and Dennis Snower (eds.) The Skills Gap and Economic Activity, Cambridge: Cambridge University Press.

Machin, Stephen and Alan Manning (1994) 'Minimum wages, wage dispersion and employment: Evidence from the UK Wages Councils', Industrial and Labor Relations Review, 47, 319-29.

Metcalf, David (1982) 'Unions and the Distribution of Earnings', British Joumal of Industrial Relations, 20, 163-69.

Metcalf, David (1989) 'Trade unions and economic performance: the British evidence', LSE Quarterly, 31, 2i-42.

Millward, Neil and Mark Stevens (1986) British Workplace Industrial Relations 1980-84, Aldershot: Gower Publishing.

Millward, Neil, Mark Stevens, David Smart and W.R. Hawes (1992) Workplace Industrial Relations in Transition, Aldershot: Dartmouth Publishing.

Minford, Patrick (1983) Unemployment: Cause and Cure, London: Martin Robertson.

Murphy, Kevin and Finis Welch (1992) 'The structure of wages', Quarterly Joumal of Economics, 107, 285-326.

Reynolds, Lloyd and Cynthia Taft (1956) The Evolution of Wage Structure, New Haven: Yale University Press.

Schmitt, John (1992) 'The changing structure of male eamings in Britain, 1974-88', LSE mimeo, forthcoming in Richard Freeman and Lawrence Katz (eds.) Changes and Differences in Wage Structures, Chicago: University of Chicago Press.

Slichter, Sumner, James Healy and Robert Livernash (1960) The Impact of Collective Bargaining on Management, Washington D.C.: The Brookings Institution.

Stewart, Mark (1983a) 'Relative eamings and union membership in the United Kingdom', Economica, 50, 111-26. 
Stewart, Mark (1983b) 'On least squares estimation when the dependent variable is grouped', Review of Economic Studies, 50, 73-53.

Stewart, Mark (1987) 'Collective bargaining arrangements, closed shops and relative pay', Economic Journal, 97, 140-56.

Stewart, Mark (1991) 'Union wage differentials in the face of changes in the economic and legal environment', Economica, 58, 155-72.

Stewart, Mark (1992) 'Do changes in collective bargaining arrangements imply declining union wage differentials into the 1980s', paper presented at Centre for Economic Performance WIRS3 Conference, January 7, 1993. 